\title{
Peripheral challenge by Small and Medium Sized Ports (SMPs) in Multi-Port Gateway Regions: the case study of northeast of China
}

\author{
Lin Feng, Ph.D., Lecturer \\ Dalian Maritime University, China \\ Theo Notteboom, Ph.D., Professor and President \\ ITMMA - University of Antwerp, Belgium
}

\begin{abstract}
This paper focuses on the role of small and medium-sized ports (SMPs) in enhancing the competitiveness and logistics performance of multi-port gateway regions and associated inland logistics systems. The concepts developed will be applied to the ports in the northeast of China, a multi-port gateway region around the Bohai Sea Economic Rim (BER). Port competition is analyzed by multi-variable methodology and generalized common characteristics of SMPs compared to gateway ports, and the similarities of SMPS and SMEs are also compared. Later in this paper, we analyze the role of a SMP in such region in different variables: (a) cargo volume and market share; (b) international connectivity; (c) relative cluster position; (d) port city and hinterland connection; and (e) logistics and distribution function. The five-dimension analysis combined with in-depth cases study of typical Yingkou port describes a profile of SMPs in the BER and provides future study possibility for more SMPs cases worldwide.
\end{abstract}

Key words: SMPs; BER; Small and medium sized enterprises (SMEs)

\section{INTRODUCTION}

The new economic background characterized by slower economic growth and highly volatile demand for international trade provides new opportunities for small and mediumsized ports (SMPs) that often are very responsive in dealing with supply chain dynamics and related logistics systems. However, there is no academic work on how SMPs grow and compete in multi-port gateway regions, a concept introduced by Notteboom $(2009 ; 2010)$. This paper mainly deals with how SMPs can survive and become competitive in multi-port gateway regions by introducing the case study of the northeast of China.

Defining SMPs demands a multifaceted approach. Often, the scale or size of a port is measured by the single variable of the cargo throughput. Thus, small ports usually refer to ports with a total cargo throughput (volume) below a certain threshold value. Feng and Notteboom (2011) defined SMPs by proposing a seven-dimension method which takes into account the port's competitive position in its port cluster region, and the position is mainly reflected in the following seven aspects: (a) volume/market share, (b) international connectivity, (c) relative cluster position, (d) hinterland capture area, (e) Gross Domestic Product (GDP) of the port city, (f) GDP of the hinterland, and $(\mathrm{g})$ logistics and distribution function. This definition will further apply into this paper in describing port competition mechanism in the northeast of China. But in this paper, we consolidate the variables into five perspectives to avoid the overlapping of the indicators: (a) cargo volume and market share; (b) international connectivity; (c) relative cluster position; (d) port city and hinterland connection; (e) logistics and distribution function. This multi-variable method is to provide a complete picture how SMPs survive and compete in a multi-port gateway region. The determents of (a), (b) and (c) stress the SMPs' role in ports competition and the main focus is on the investigation of competition dynamics between SMPs and big ports. The variables of (d) and (e) will study how SMP s connect with and exert economic impact on the hinterland. The last variable is put SMPs in a logistics system to assess their potential and competitiveness, especially from the perspective of the inland port and intermodality. Veldman and Bückmann (2003) developed a model on container port competition and port choice in the Antwerp-Hamburg range. The study excluded the ports of Amsterdam and Zeebrugge due to their smaller market share. In recent models on port system development, SMPs are seen to be instrumental to the "peripheral port challenge" (and thus port system deconcentration, see e.g. Slack and Wang, 2002 and Notteboom, 2005). Moreover, SMPs also function more in "port regionalization" processes (Notteboom and Rodrigue, 2005) and are key to the formation of "multiport gateway regions" (Notteboom, 2010) characterized by routing flexibility and inter-port competition and coordination. In contrast to bigger ports, small ports show a slightly larger variance in growth rate (Ding, 2005). SMPs develop in an independent way, which requires ports to find their specific competitive advantage, or in a cooperative way, which seeks 
cooperation with neighboring bigger ports of the same multiport gateway region. Firstly, SMPs'strategies can focus on the hinterland connections in competition with bigger ports. Feng and Notteboom (2011) studied the empirical case of Yingkou port in the logistics system of the Bohai Sea of China, which puts Yingkou port into a more competitive position in contrast to dominant ports in such area. Secondly, SMPs often look for a cost advantage in specific niche markets. Clark et al. (2001) demonstrated how small ports could compete with big ports in specialized markets. Thirdly, SMPs might also secure growth by serving the dominant ports in the multi-port gateway region. Such a strategy demands close cooperation between ports.

The dimensions for SMPs are similar to how we define SMEs. Although different countries have specific definitions on conceptualizing SMEs, certain criteria exist in the following aspects: SMEs by growth and motivation in more traditional categories such as size, market sector or business-to-business or business-to-consumer E-commerce proved to be appropriate for both firms in traditional industries and e-commerce.

- Employment: European Union categorizes companies with fewer than 10 employees as "micro", those with fewer than 50 employees as "small", and those with fewer than 250 as "medium". Successful SMEs place greater emphasis on soft issues (people) than hard issues (technology and structure). The management skills and concepts of the founders are deemed much more important than their technical skills. Employee skills are of crucial concern and can be most effectively developed in a nurturing working environment. Nevertheless the impact of business founders on organizational success remains the leading factor.

- Organizational structure: compared to large enterprises, most SMEs have simplified organization structure, even without clear labor division in order to decrease human cost and more flexible strategy adoption.

- Percentage of all production factors in total product cost (or product price): usually, production factors of SMEs are more localized with high marginal cost. Among the production factors, the weight of technology innovation is comparatively low while labor costs and marketing costs are high.

- Niche market: SMEs are in subordinating position of an industrial chain dominated by big firms and most SMEs engage in perfectly competitive market with low entry barrier. Some SMEs can be competitive in niche market.

When comparing SMEs and SMPs, the benchmarking ground should also be paid attention to. SMEs are defined more generally covering all industries and all forms of firms, thus it's similar to how we define SMPs. However, SMPs are specifically referred to ports industry. If we look at how a port is organized, we may find there are two forms; either a small port composed of small and big companies or a big port combined with small companies. Therefore, analyzing SMPs in a big port is more prone to referring to the SMEs cluster while SMPs of a small port are more like individual SME. Currently, globally SMEs account for $99 \%$ of business numbers and $40 \%$ to $50 \%$ of GDP, while in port industry, big ports contribute more to the global freight.

There are several reasons why the role of SMPs in multiport gateway regions might be somewhat overlooked. First, most SMPs have a close connection with the local port city and the direct hinterland. This implies that the supply chain perspective of SMPs is often wrongly considered as only of local importance. Second, large ports are often facing a more visible array of local constraints that impair their growth and efficiency (Notteboom and Rodrigue, 2005). Most SMPs typically have easier access to the (local) inland ports or relevant logistics system. The development issues in SMPs receive far less attention in the specialized press and therefore might seem less pressing. Traditionally, SMPs are regarded as being in a disadvantageous position compared to large ports in terms of the available resources supporting their development. However, we argue that most SMPs play an indispensable role in the development of multi-port gateway regions around the world. The development of SMPs depends on either location advantages or their contribution in improving the logistics network of the multi-port gateway region. As SMPs typically have a smaller scale, they are often more agile and flexible in dealing with new market-based challenges, e.g. by redefining the strategic mission of the port toward a specialized/niche port complementing the wider multi-port gateway region. There are several reasons why the role of SMPs in multi-port gateway regions might be somewhat overlooked. First, most SMPs have a close connection with the local port city and the direct hinterland. This implies that the supply chain perspective of SMPs is often wrongly considered as only of local importance. Second, large ports are often facing a more visible array of local constraints that impair their growth and efficiency (Notteboom and Rodrigue, 2005). Most SMPs typically have easier access to the (local) inland ports or relevant logistics system. The development issues in SMPs receive far less attention in the specialized press and even might be ignored. Traditionally, SMPs are regarded as ones in a disadvantageous position compared to large ports in terms of the available resources supporting their development. However, we argue that most SMPs play an indispensable role in the development of multiport gateway regions around the world. The development of SMPs depends on either location advantages or their contribution in improving the logistics network of the multiport gateway region. As SMPs typically have a smaller scale, they are often more agile and flexible in dealing with new market-based challenges. Thus, it is necessary to complement the wider multi-port gateway region by redefining the strategic mission of the port toward a specialized/niche port.

The above discussion suggests that the study of SMPs is not only relevant but also necessary in order to improve the competitiveness of multi-port gateway regions and to strengthen their role in facilitating network-based supply chain.

In August 2006, the Chinese State Council discussed and released the National Seaports Layout Plan, where Chinese seaports were classified into five port regions: the Bohai Sea Economic Rim (BER), Yangtze River Delta (YRD), Southeastern Coastal Ports Cluster, Pearl River Delta (PRD) and Southwestern Coastal Port Cluster. In all five port regions sharing some common characteristics, each one is composed of more than one gateway port (also conceived as hub ports or centrality) and most gateway ports in China serve high dependence on foreign trade. Within the same port region, gateway ports are usually considered to compete with each other directly owing to adjacent geographical locations. Other peripheral ports act as assisting ports and serve their gateway ports. However, this classification blurred port relationship within the same port region with more peripheral ports springing up. The anticipated networking between hubs and assisting ports didn't form, but fast increase of these "assisting" ports put new competition pressure on hub ports. Hence, we introduce the concept of SMPs in this paper to re-construct the competition mechanism in multi-port gateway region. To verify the application of SMPs, we assume this concept can only be employed to explain the port in the same port region, i.e. Yingkou port with 225.01 million tons of cargo volume in 2010 , the $10^{\text {th }}$ large seaport in China, ranks the sixth place in 
the BER. In other words, a large port nationwide is measured as a medium sized port in the BER context. In current China port statistics, ports of "above Designated Size" are included but definition of "designated sized" is not specified. In this paper, we introduced definition of SMPs by classifying ports into three levels: big, medium-sized and small ports according to the five-dimension method discussed above. In Sections III, IV and IIV, we provide an in-depth description of ports with similar characteristics and draw more academic attention to SMPs. In this paper we mainly discuss the role of SMPs in enhancing the competitiveness and hinterland identification of multi-port gateway regions.

\section{GENERAL PROFILE OF MULTI-PORT GATEWAY REGION IN THE BER}

The multi-port gateway region in the northeast of China (defined as Bohai Sea Economic rim, BER) has seen a strong growth in recent years partly as a result of the efforts of the Chinese government to promote the region as a third major growth pole after PRD and YRD regions. The ports in the BER are becoming more important in the worldwide spoke-and-hub system as well. Major gateways of Dalian, Tianjin and Qingdao climbed in the world ranking and growth in Yingkou port even reached by $25 \%$ in 2009 (Table 1). Previous port competition analysis usually emphasized gateway port and the rest ports were conceived as assisting ports that couldn't form direct competition over these hub ports. With the rapid increase of SMPs, original port competition hierarchy has been blurred, and the periphery challenge by Yingkou ports, as well as other SMPs puts competitive pressure on the BER port system.
The BER is interpreted as the economic area around the Bohai Sea and a part of the coastal areas along the South Sea, which are also named as the Golden Coastline. The BER includes Beijing (Jing), Tianjin (Jin, Municipality), Liaoning (Liao), Hebei (Ji), Shanxi (Jin), Shandong (Lu) and eastern Inner Mongolia, covering 1.12 million square kilometers totally. More than 60 ports are dispersed along 5,319 kilometers of coastline in the BER. According to the data availability, we include 11 ports in this paper as our research objectives (Figure 1).

The BER is divided into three subordinate multi-port gateway regions in terms of geographical locations (Table 2): Liaoning, Jin-Ji and Shandong Bay. In contrast to other port clusters in China, the BER port group is more evenly distributed. Four ports of Dalian, Yingkou, Jinzhou and Dandong constitute the Liaoning port group, occupying $25.4 \%$ of total cargo volume in the BER in 2010. Comparatively, ports of Tianjin, Qinhuangdao, Tangshan and Huanghua are in the center of the BER, with $44.3 \%$ of market share, and the rest of ports serve Shandong bay.

Port competition in the BER can be re-identified if we include more ports, and the Pusan Port in the South Korea is exemplified as a typical case. The Pusan port deals with most transshipment importing from and exporting to China, Japan and other areas, and has formed direct competition over load centers (Dalian, Tianjin and Qingdao) of the BER. These gateway ports are mainly driven by foreland and compete with each other for international trade cargoes. The Pusan Port and three gateways ports of China have no cooperation and in between these ports direct competition exists. Direct competition in question covers two meanings: Above all

Tab. 1. Ports of BER in the world top container ports rank in 2009

\begin{tabular}{|c|c|c|c|c|c|}
\hline $\begin{array}{c}\text { Rank in } \\
\mathbf{2 0 0 8}\end{array}$ & $\begin{array}{c}\text { Rank in } \\
\mathbf{2 0 0 9}\end{array}$ & Port & $\begin{array}{c}\text { Throughput in 2008 } \\
\text { (TEU) }\end{array}$ & $\begin{array}{c}\text { Throughput in 2009 } \\
\text { (TEU) }\end{array}$ & Change \\
\hline 59 & 41 & Yingkou & 2036400 & 2537000 & $25 \%$ \\
\hline 75 & 70 & Yantai & 1510000 & 1401100 & $-7 \%$ \\
\hline 24 & 22 & Dalian & 4500495 & 4550000 & $1 \%$ \\
\hline 14 & 11 & Tianjin & 8500000 & 8700000 & $2 \%$ \\
\hline 10 & 9 & Qingdao & 10320000 & 10260000 & $-1 \%$ \\
\hline
\end{tabular}

Source: author's elaboration on China port yearbook

Tab. 2. Multi-port gateway regions in the BER - key characteristics

\begin{tabular}{|c|c|c|c|c|c|}
\hline Port region & $\begin{array}{l}\text { Gateway } \\
\text { port }\end{array}$ & $\begin{array}{l}\text { Positioning } \\
\text { of gateway } \\
\text { port } \\
\end{array}$ & $\begin{array}{l}\text { Assisting } \\
\text { ports }\end{array}$ & $\begin{array}{l}\text { Cargo } \\
\text { category }\end{array}$ & Hinterland \\
\hline Liaoning & Dalian & $\begin{array}{l}\text { Northeastern } \\
\text { Asian } \\
\text { International } \\
\text { Shipping } \\
\text { Center }\end{array}$ & $\begin{array}{l}\text { Yingkou } \\
\text { Jinzhou } \\
\text { Dandong }\end{array}$ & $\begin{array}{l}\text { Petroleum, } \\
\text { grain, ore, } \\
\text { steel }\end{array}$ & $\begin{array}{c}\text { Liaoning } \backslash \text { Jilin } \backslash \text { Heilongjian } \\
\text { Provinces, eastern Inner } \\
\text { Mongolia }\end{array}$ \\
\hline $\begin{array}{l}\text { Shandong } \\
\text { Bay }\end{array}$ & Qingdao & $\begin{array}{l}\text { Northeastern } \\
\text { Asian } \\
\text { International } \\
\text { Shipping } \\
\text { Center } \\
\end{array}$ & $\begin{array}{l}\text { Yantai } \\
\text { Rizhao } \\
\text { Weihai }\end{array}$ & $\begin{array}{l}\text { Coal, } \\
\text { petroleum, } \\
\text { ore, container }\end{array}$ & $\begin{array}{c}\text { Shandong Bay, Henang } \\
\text { Provinces }\end{array}$ \\
\hline Jin-Ji & Tianjin & $\begin{array}{l}\text { Northern } \\
\text { Shipping and } \\
\text { Logistics } \\
\text { Center of } \\
\text { China }\end{array}$ & $\begin{array}{l}\text { Qinhuangdao } \\
\text { Tangshan }\end{array}$ & $\begin{array}{l}\text { coal and } \\
\text { derivatives, } \\
\text { steel, ore }\end{array}$ & $\begin{array}{l}\text { Beijing, Tianjin, Hebei, } \\
\text { Shanxi }\end{array}$ \\
\hline
\end{tabular}

Note: Positioning of gateway ports: the role and of these gateway ports outlined by central Chinese government 


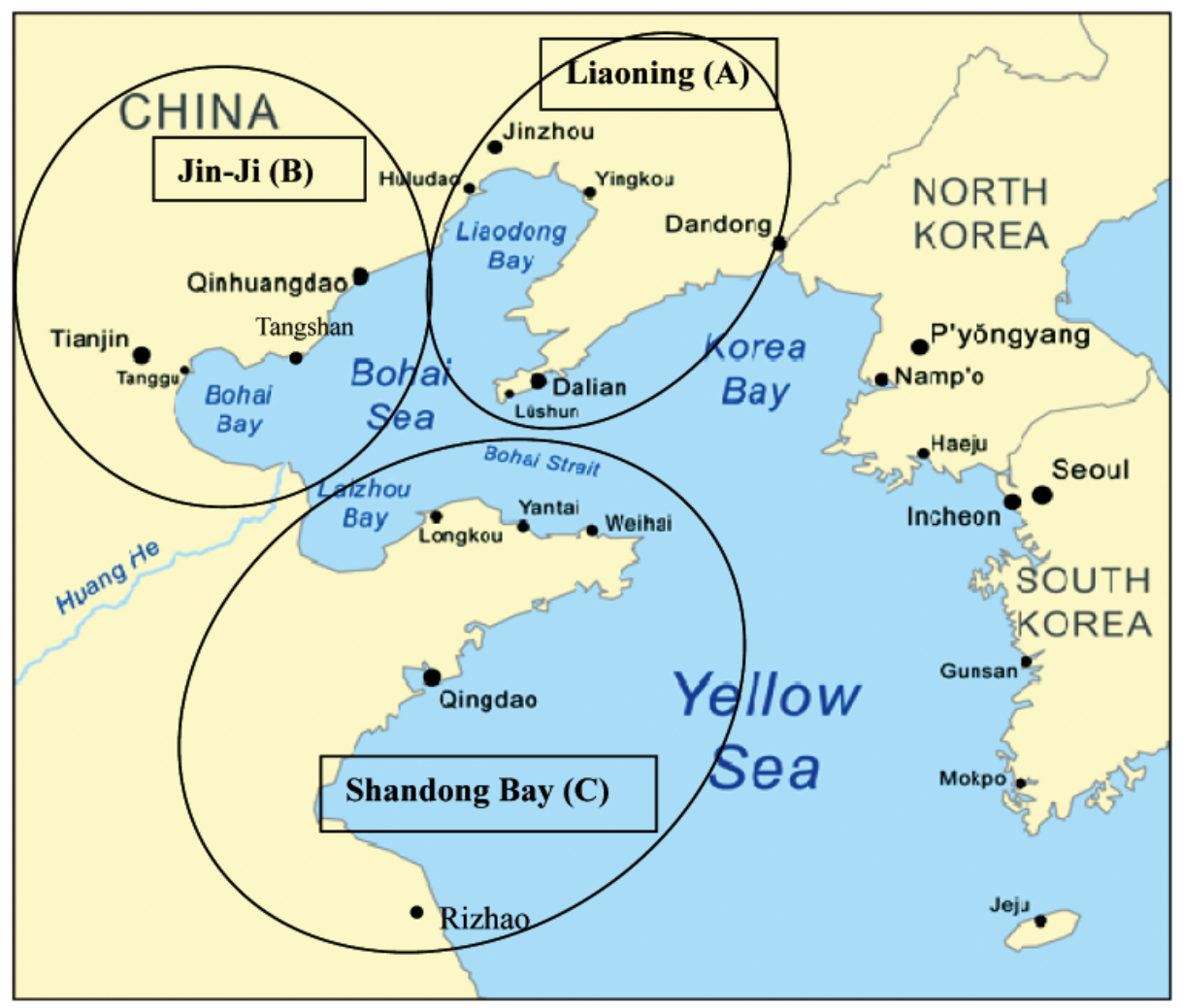

Fig. 1. Multi-port gateway regions in the BER

three Chinese hub ports face challenge from the Pusan Port due to cost factor, and it means cargos previously handled by these ports are now transported to the Pusan Port and then to other foreign ports, say Longbeach, etc. In the Pusan port, the Terminal Handling Charge (THC) is about $\$ 40$ per container in contrast to average $\$ 88$ in Chinese gateway ports in the BER. Besides, in between three Chinese gateways ports, competition also becomes intense because all these ports are driven by foreland and depend on international trade. The port competition in between one big transshipment port (Pusan) and three hub ports (Tianjin, Qingdao and Dalian) in the BER is similar to the PRD region in the south of China with existence of Hong Kong, Shenzhen and Guangzhou ports. In the PRD, the Hong Kong Port bears most transshipment, Shenzhen holds high percentage of international trade cargoes and Guangzhou serves more for domestic trade.

\section{SMPS FEATURES AND PORT COMPETITION}

\subsection{Volume/market share}

In order to identify port categories in the BER, we integrate data in total cargo volume, cargo traffic in the international trade and container traffic as measurement. All data are available exactly in the China Port Yearbook. Accordingly, we calculate the data of cargo traffic and container traffic and corresponding share (Table 3 ).

By two dimensions ( $\mathrm{X}$ axis as total cargo volume, $\mathrm{Y}$ axis as container traffic), we classify ports in the BER into three categories: big, medium sized and small ports. Qingdao, Tianjin and Dalian are as big ports, with $46.25 \%$ of total market share.

Tab. 3. Port ranking, cargo volume and container traffic in the BER (2010)

\begin{tabular}{|c|c|c|c|c|c|}
\hline Rank & $\begin{array}{l}\text { Port (City/ } \\
\text { region) }\end{array}$ & $\begin{array}{l}\text { Total cargo volume } \\
\text { in million tons }(\mathrm{A})\end{array}$ & $\begin{array}{c}\text { Container traffic } \\
\text { TEUs in thousands (B) }\end{array}$ & $\begin{array}{l}\text { Market share } \\
\text { (A/total A) }\end{array}$ & $\begin{array}{c}\text { Centralization } \\
\text { degree }\end{array}$ \\
\hline 1 & Tianjin & 400.45 & 9439.92 & $17.44 \%$ & \multirow{3}{*}{$46.25 \%$} \\
\hline 2 & Qingdao & 360.42 & 11848.51 & $15.69 \%$ & \\
\hline 3 & Dalian & 301.31 & 5060.88 & $13.12 \%$ & \\
\hline 4 & Qinhuangdao & 257.14 & 340.04 & $11.20 \%$ & \multirow{5}{*}{$46.62 \%$} \\
\hline 5 & Tangshan & 250.62 & 244.52 & $10.91 \%$ & \\
\hline 6 & Yingkou & 225.01 & 2679.48 & $9.80 \%$ & \\
\hline 7 & Rizhao & 188.00 & 1061.01 & $8.19 \%$ & \\
\hline 8 & Yantai & 150.00 & 1527.31 & $6.53 \%$ & \\
\hline 9 & Jinzhou & 60.08 & 754.79 & $2.62 \%$ & \multirow{3}{*}{$7.13 \%$} \\
\hline 10 & Dandong & 55.05 & 319.72 & $2.40 \%$ & \\
\hline 11 & Weihai & 48.66 & 441.73 & $2.12 \%$ & \\
\hline \multicolumn{2}{|r|}{ Total } & 2296.74 & 33717.90 & $100.00 \%$ & $100.00 \%$ \\
\hline
\end{tabular}

Source: author's elaboration on China port year book 2011. Total cargo volumes include transshipment and transit volumes. 


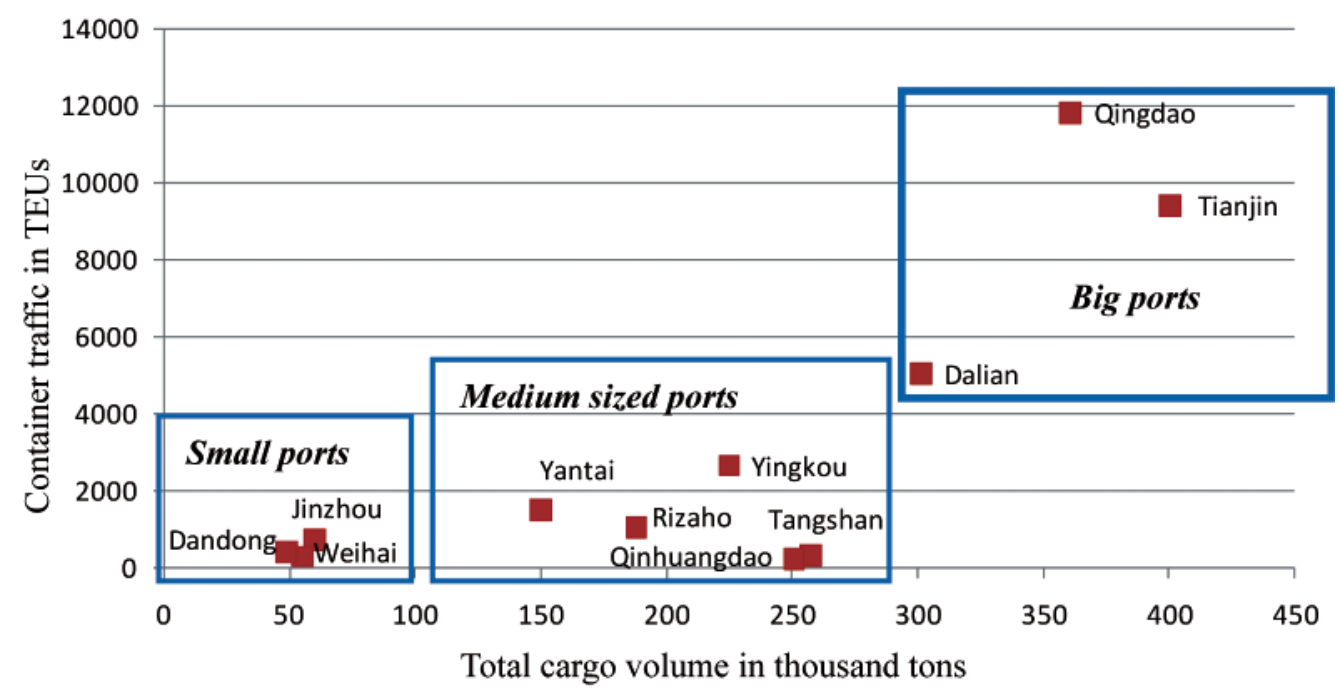

Fig. 2. Port hierarchy in terms of total cargo volume and container traffic
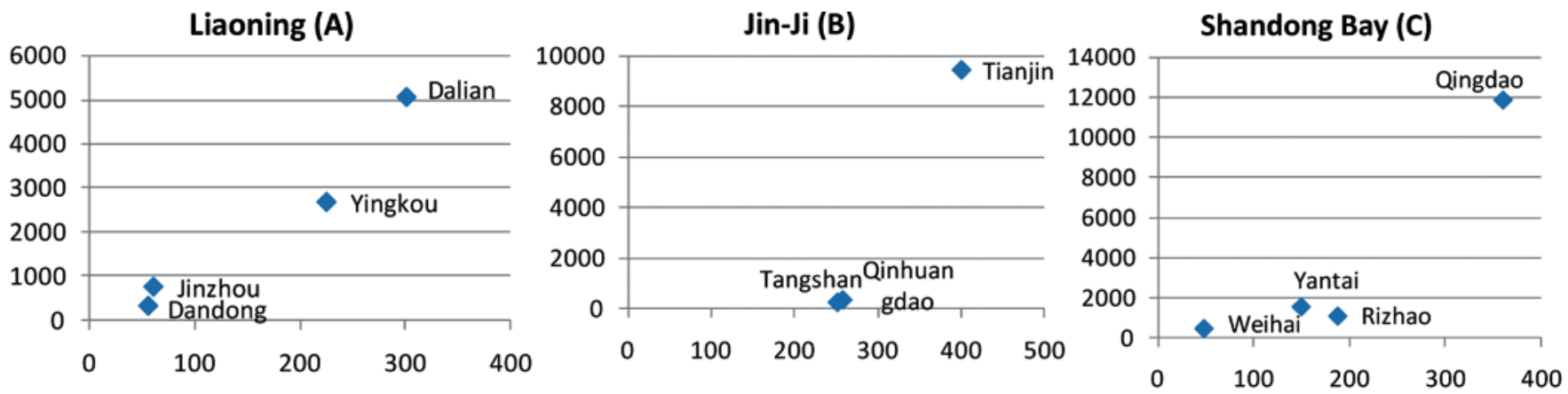

Fig. 3. Port hierarchy distribution in terms of total cargo volume.

Note: $X$ axis in thousand tons and $Y$ axis container traffic in TEU. Note different scales on the $Y$ axis

Qinhuangdao, Tangshan, Yingkou, Rizhao and Yantai are medium sized ports, with $46.62 \%$ of total market share, while Jinzhou, Dandong and Weihai are defined as small ports, weighing $7.13 \%$ of total market shares (Figure 2). The fierce competition is present among medium sized ports.

If we have a deeper look at port competition mechanism in each separate port cluster, we'll find subtle difference (Figure 3). In the Liaoning port group, the gap between big port (Dalian ports) and medium sized one (Yingkou port) is narrowed to the hilt, so as for two small ports of Jinzhou and Dandong. Therefore, in Liaoning, ports competition exists between big port and medium sized ports, and the port "inbetweeness" competition phenomenon is obvious. In contrast, we get to know more competition in between medium sized ports in the Jin-Ji and the Shandong bay, while the difference between big ports and medium sized ports are too far to be defined as direct competition.

To better measure port competition and position of SMPs, we introduce Herfindahl-Hirschman Index (HHI index) to measure market concentration.

$$
\mathrm{H}=\sum_{\mathrm{i}=1}^{\mathrm{N}} \mathrm{s}_{\mathrm{i}}^{2}
$$

Where $\mathrm{s}_{\mathrm{i}}$ is the market share of port $\mathrm{i}$ in the market, and $\mathrm{N}$ is the number of ports.

$$
\begin{aligned}
& \mathrm{H}_{(\mathrm{A})}=0.4412 \\
& \mathrm{H}_{(\mathrm{B})}=0.3567 \\
& \mathrm{H}_{(\mathrm{C})}=0.4007 \text { (calculated from table 4) }
\end{aligned}
$$

HHI index of the three regions are above 0.25 , indicating a high concentration. The Liaoning with 0.4412 means the highest concentration degree in the BER. Market concentration in BER shows a high degree, but HHI index can't measure the future uncertainty and to what extent the rise of SMPs can threaten dominance of hub port. Thus we introduce

\begin{tabular}{|c|c|c|}
\hline $\operatorname{Port} / A \eta_{i, j}, \delta_{i, j}$ & $A \eta_{i, j}$ & $\boldsymbol{\delta}_{\mathbf{i}, \mathbf{j}}$ \\
\hline \multicolumn{3}{|c|}{ Liaoning (A) } \\
\hline Dalian & $60.30 \%$ & 0.0952 \\
\hline Yingkou & $25.88 \%$ & 0.0337 \\
\hline Jinzhou & $9.22 \%$ & 0.0006 \\
\hline Dandong & $4.60 \%$ & 0.0167 \\
\hline \multicolumn{3}{|c|}{ Jin-Ji (B) } \\
\hline Tianjin & $45.54 \%$ & 0.0093 \\
\hline Qinhuangdao & $35.11 \%$ & 0.0549 \\
\hline Tangshan & $10.54 \%$ & 0.0453 \\
\hline Huanghua & $8.80 \%$ & 0.0281 \\
\hline \multicolumn{3}{|c|}{ Shandong Bay (C) } \\
\hline Qingdao & $56.78 \%$ & 0.0428 \\
\hline Rizhao & $22.65 \%$ & 0.0155 \\
\hline Yantai & $15.67 \%$ & 0.0089 \\
\hline Weihai & $4.90 \%$ & 0.0007 \\
\hline
\end{tabular}
three definitions here: centralization degree $(\eta)$, average centralization degree $\left(A \eta_{i, j}\right)$ and variance $(\delta)$.

Tab. 4. Average centralization degree and variance of ports in the BER

$\eta_{i, j}=$ cargo volume of port $\mathrm{i} /$ cargo volume of port cluster $\mathrm{j}$. Measures the market share of a port in corresponding port cluster. We adopt this figure to analyze port competition intensity. 


$$
A \eta_{i, j}=\frac{\sum \eta_{i, j}}{10}(i, j=1 \ldots n)
$$

Average market share in 10 years.

$$
\delta_{i, j}=\Sigma\left(\eta_{i, j}-A \eta_{i, j}\right)^{2},(i, j=1 \ldots 10)
$$

Measure what extent the position of a port will be changed, the higher value of $\delta$, the high risk that a port's position could be changed.

If we compare $\eta_{i, j}$ and $A \eta_{i, j}$ values of Liaoning (A), we'll find more market shares are centralized among Dalian and Yingkou, and variance $(\delta)$ of Dalian is 0.0952 , highest among all ports in the BER, which indicates the most possible peripheral challenge by medium-sized ports in Liaoning port competition structure. By contrast, variances $(\delta)$ in Tianjin and Qingdao are 0.0093 and 0.0428 respectively, illustrating a relatively stable port hierarchy. Decrease of the underlying change factors means the threat from SMPs in these two regions declines (Tables 2, 3 and 4). Therefore, the future port competition mechanism in Liaoning contains more uncertainties and changes while relations between hubs and SMPs in the other two regions keep relatively stable. The change factor involved in this paper has excluded the change possibility from external ports. If we include more adjacent ports in other nations, such stability may contain more changing factors.

\subsection{International port connectivity in the BER}

Beyond considering the size of ports to differentiate them, we classify ports into three categories depending on the cargo source only associated with container traffic (Table 7). Through

Tab. 5. Total cargo volume in the BER 2001-2010

\begin{tabular}{|ccccccccccc|}
\hline Port/Volume & $\mathbf{2 0 0 1}$ & $\mathbf{2 0 0 2}$ & $\mathbf{2 0 0 3}$ & $\mathbf{2 0 0 4}$ & $\mathbf{2 0 0 5}$ & $\mathbf{2 0 0 6}$ & $\mathbf{2 0 0 7}$ & $\mathbf{2 0 0 8}$ & $\mathbf{2 0 0 9}$ & $\mathbf{2 0 1 0}$ \\
\hline Liaoning (A) & $\mathbf{1 3 6 . 7 7}$ & $\mathbf{1 5 3 . 8 2}$ & $\mathbf{1 8 3 . 1 8}$ & $\mathbf{2 3 9 . 4 9}$ & $\mathbf{2 9 1 . 2 5}$ & $\mathbf{3 6 8 . 8 0}$ & $\mathbf{4 0 6 . 4 6}$ & $\mathbf{4 7 6 . 4 6}$ & $\mathbf{5 4 4 . 1 5}$ & $\mathbf{6 4 1 . 4 5}$ \\
Dalian & 100.47 & 108.51 & 126.02 & 145.16 & 170.85 & 200.46 & 222.86 & 245.88 & 272.03 & 301.31 \\
Yingkou & 25.20 & 31.27 & 40.09 & 59.78 & 75.37 & 94.77 & 122.07 & 150.85 & 176.03 & 225.01 \\
Jinzhou & 11.10 & 14.04 & 17.07 & 24.55 & 30.03 & 31.57 & 35.15 & 47.23 & 52.59 & 60.08 \\
Dandong & & & & 10.00 & 15.00 & 42.00 & 26.38 & 32.50 & 43.50 & 55.05 \\
\hline Jingji (B) & $\mathbf{2 3 8 . 2 9}$ & $\mathbf{2 5 5 . 7 2}$ & $\mathbf{3 3 9 . 7 7}$ & $\mathbf{4 2 8 . 5 7}$ & $\mathbf{5 1 0 . 9 7}$ & $\mathbf{5 9 5 . 6 5}$ & $\mathbf{7 0 7 . 5 1}$ & $\mathbf{7 9 6 . 5 8}$ & $\mathbf{8 8 9 . 8 6}$ & $\mathbf{1 0 0 4 . 2 1}$ \\
Tianji & 113.69 & 129.06 & 161.82 & 206.19 & 240.69 & 257.60 & 309.46 & 355.93 & 381.11 & 400.45 \\
Qinhuangdao & 113.02 & 111.67 & 125.62 & 150.37 & 169.00 & 204.89 & 248.93 & 252.31 & 249.42 & 257.14 \\
Tangshan & 11.02 & 14.65 & 20.83 & 26.02 & 33.65 & 51.71 & 65.79 & 108.54 & 175.59 & 250.62 \\
Huanghua & 0.56 & 0.34 & 31.50 & 45.99 & 67.63 & 81.45 & 83.33 & 79.80 & 83.74 & 96.00 \\
\hline Shandong Bay & & & & & & & & & & \\
(C) & $\mathbf{1 6 2 . 4 8}$ & $\mathbf{1 8 9 . 8 4}$ & $\mathbf{2 2 6 . 6 4}$ & $\mathbf{2 6 1 . 4 6}$ & $\mathbf{3 3 1 . 3 7}$ & $\mathbf{4 1 3 . 0 1}$ & $\mathbf{5 1 7 . 8 9}$ & $\mathbf{5 8 5 . 2 6}$ & $\mathbf{6 6 1 . 4 6}$ & $\mathbf{7 4 7 . 0 8}$ \\
Qingdao & 103.98 & 122.13 & 140.90 & 162.65 & 186.78 & 224.15 & 265.02 & 300.29 & 315.46 & 360.42 \\
Rizhao & 29.33 & 31.36 & 45.07 & 51.08 & 84.21 & 110.07 & 130.63 & 151.02 & 181.31 & 188.00 \\
Yantai & 21.90 & 26.89 & 29.36 & 34.31 & 45.06 & 60.76 & 101.29 & 111.89 & 123.51 & 150.00 \\
Weihai & 7.27 & 9.46 & 11.31 & 13.42 & 15.32 & 18.03 & 20.95 & 22.06 & 41.18 & 48.66 \\
\hline Total (A+B+C) & 537.54 & 599.38 & 749.59 & 929.52 & 1133.59 & 1377.46 & 1631.86 & 1858.30 & 2095.47 & 2392.74 \\
\hline
\end{tabular}

Note: million tons except noted. Since 2007, the data for Yantai includes Yantai port and Longkou port. Source: author's elaboration on year book 2001-2010.

\begin{tabular}{|c|c|c|c|c|c|c|c|c|c|c|}
\hline Port $/ \eta_{i, j}$ & 2001 & 2002 & 2003 & 2004 & 2005 & 2006 & 2007 & 2008 & 2009 & 2010 \\
\hline \multicolumn{11}{|c|}{ Liaoning (A) } \\
\hline Dalian & $73.46 \%$ & $70.54 \%$ & $68.80 \%$ & $60.61 \%$ & $58.66 \%$ & $54.35 \%$ & $54.83 \%$ & $51.61 \%$ & $49.99 \%$ & $46.97 \%$ \\
\hline Yingkou & $18.43 \%$ & $20.33 \%$ & $21.89 \%$ & $24.96 \%$ & $25.88 \%$ & $25.70 \%$ & $30.03 \%$ & $31.66 \%$ & $32.35 \%$ & $35.08 \%$ \\
\hline Jinzhou & $8.12 \%$ & $9.13 \%$ & $9.32 \%$ & $10.25 \%$ & $10.31 \%$ & $8.56 \%$ & $8.65 \%$ & $9.91 \%$ & $9.66 \%$ & $9.37 \%$ \\
\hline Dandong & $0.00 \%$ & $0.00 \%$ & $0.00 \%$ & $4.18 \%$ & $5.15 \%$ & $11.39 \%$ & $6.49 \%$ & $6.82 \%$ & $7.99 \%$ & $8.58 \%$ \\
\hline \multicolumn{11}{|c|}{ Jin-Ji (B) } \\
\hline Tianjin & $47.71 \%$ & $50.47 \%$ & $47.63 \%$ & $48.11 \%$ & $47.10 \%$ & $43.25 \%$ & $43.74 \%$ & $44.68 \%$ & $42.83 \%$ & $39.88 \%$ \\
\hline Qinhuangdao & $47.43 \%$ & $43.67 \%$ & $36.97 \%$ & $35.09 \%$ & $33.07 \%$ & $34.40 \%$ & $35.18 \%$ & $31.67 \%$ & $28.03 \%$ & $25.61 \%$ \\
\hline Tangshan & $4.62 \%$ & $5.73 \%$ & $6.13 \%$ & $6.07 \%$ & $6.59 \%$ & $8.68 \%$ & $9.30 \%$ & $13.63 \%$ & $19.73 \%$ & $24.96 \%$ \\
\hline Huanghua & $0.24 \%$ & $0.13 \%$ & $9.27 \%$ & $10.73 \%$ & $13.24 \%$ & $13.67 \%$ & $11.78 \%$ & $10.02 \%$ & $9.41 \%$ & $9.56 \%$ \\
\hline \multicolumn{11}{|c|}{ Shandong Bay (C) } \\
\hline Qingdao & $64.00 \%$ & $64.33 \%$ & $62.17 \%$ & $62.21 \%$ & $56.37 \%$ & $54.27 \%$ & $51.17 \%$ & $51.31 \%$ & $47.69 \%$ & $48.24 \%$ \\
\hline Rizhao & $18.05 \%$ & $16.52 \%$ & $19.89 \%$ & $19.54 \%$ & $25.41 \%$ & $26.65 \%$ & $25.22 \%$ & $25.80 \%$ & $27.41 \%$ & $25.16 \%$ \\
\hline Yantai & $13.48 \%$ & $14.16 \%$ & $12.95 \%$ & $13.12 \%$ & $13.60 \%$ & $14.71 \%$ & $19.56 \%$ & $19.12 \%$ & $18.67 \%$ & $20.08 \%$ \\
\hline Weihai & $4.47 \%$ & $4.98 \%$ & $4.99 \%$ & $5.13 \%$ & $4.62 \%$ & $4.37 \%$ & $4.05 \%$ & $3.77 \%$ & $6.23 \%$ & $6.51 \%$ \\
\hline
\end{tabular}

Tab. 6. Centralization degree of the ports in the BER

Source: author's elaboration on China port year book 2011. 
Tab. 7. International connectivity of the ports in the BER 2010

\begin{tabular}{|c|c|c|c|c|c|c|}
\hline Rank & $\begin{array}{c}\text { Port } \\
(\text { City/region) }\end{array}$ & $\begin{array}{c}\text { Container cargo } \\
\text { traffic TEUs in } \\
\text { thousands (B+C) }\end{array}$ & $\begin{array}{c}\text { Container } \\
\text { Cargo traffic in } \\
\text { international } \\
\text { trade TEUs in } \\
\text { thousands (B) }\end{array}$ & $\begin{array}{c}\text { Container } \\
\text { Share of int. } \\
\text { trade traffic } \\
(\mathbf{B} /(\mathbf{B}+\mathbf{C}) * \mathbf{1 0 0 \% )}\end{array}$ & $\begin{array}{c}\text { Cargo traffic } \\
\text { in domestic } \\
\text { trade TEUs in } \\
\text { thousands (C) }\end{array}$ & $\begin{array}{c}\text { Share of domestic } \\
\text { trade traffic } \\
(\mathbf{C} /(\mathbf{B}+\mathbf{C}) * \mathbf{1 0 0} \%)\end{array}$ \\
\hline 1 & Qingdao & 11848.51 & 10046.05 & $84.79 \%$ & 1802.46 & $15.21 \%$ \\
\hline 2 & Dalian & 5060.88 & 4065.79 & $80.34 \%$ & 995.09 & $19.66 \%$ \\
\hline 3 & Tianjin & 9439.92 & 5422.86 & $57.45 \%$ & 4003.42 & $42.41 \%$ \\
\hline 4 & Weihai & 441.73 & 221.07 & $50.05 \%$ & 222.30 & $50.33 \%$ \\
\hline 5 & Qinhuangdao & 340.04 & 122.83 & $36.12 \%$ & 217.21 & $63.88 \%$ \\
\hline 6 & Yantai & 1527.31 & 366.39 & $23.99 \%$ & 1160.91 & $76.01 \%$ \\
\hline 7 & Dandong & 319.72 & 54.94 & $17.18 \%$ & 264.79 & $82.82 \%$ \\
\hline 8 & Tangshan & 244.52 & 23.09 & $9.44 \%$ & 221.43 & $90.56 \%$ \\
\hline 9 & Rizhao & 1061.01 & 29.39 & $2.77 \%$ & 1031.62 & $97.23 \%$ \\
\hline 10 & Yingkou & 2679.48 & 48.08 & $1.79 \%$ & 2631.41 & $98.21 \%$ \\
\hline 11 & Jinzhou & 754.79 & 10.98 & $1.45 \%$ & 743.81 & $98.55 \%$ \\
\hline
\end{tabular}

Source: author's elaboration on China port yearbook 2010.

assessment of international trade cargo percentage, Tianjin, Qingdao, Dalian and Weihai are of high degree of connection with international trade, i.e., highest of Qingdao with $84.79 \%$ and comparatively low of Weihai $50.05 \%$. However, we need to draw attention that the Weihai port in this category is a special case because its small total volume and part of volume derives from transshipment of Qingdao. Therefore, even with high degree of international connectivity, Weihai can't be defined as a hub port. Port competition in the Shandong Bay is decentralized in terms of international port connectivity. We consider the second category of ports as domestic trade driven ports with medium degree of international connectivity. Three ports in this category, Qinhuangdao, Yantai and Dandong are located in three different port clusters. Furthermore in the third category, Yingkou, Tangshan, Rizhao and Jinzhou ports are domestic trade driven ports with comparatively low degree of international connectivity (Figure 4).

By analysis in port size and cargo classification, we therefore define hub ports in the BER as the ports of Qingdao,
Tianjin and Dalian. Port competition in the BER has the following characteristics: first, hub port competition is more intense as all three ports are similarly highly international trade driven. Second, Hub port and SMPs competition has reduced in Liaoning and Jin-Ji port cluster because Dalian and Yingkou are driven by international trade and domestic trade respectively, and similar to Tianjin and Qinhuangdao. Even closely located, SMPs and hub ports serve prominent roles. In comparison, the port competition in the Shandong Bay is more fierce, and the ports of Qingdao, Weihai and Yantai share high degree international trade dependence. In general, competition in between SMPs and central ports in the BER confines to regional area. For instance, Yingkou port's growth can challenge dominant position of Dalian port but there is no evidence that it has threat over Tianjin or Qingdao port. Some mediumsized ports in the BER are becoming regional centers as most SMPs in this region are hinterland-driven that requires more for accessibility to hinterland. The process of strengthening consecutiveness to hinterland speeds up their increasing role as

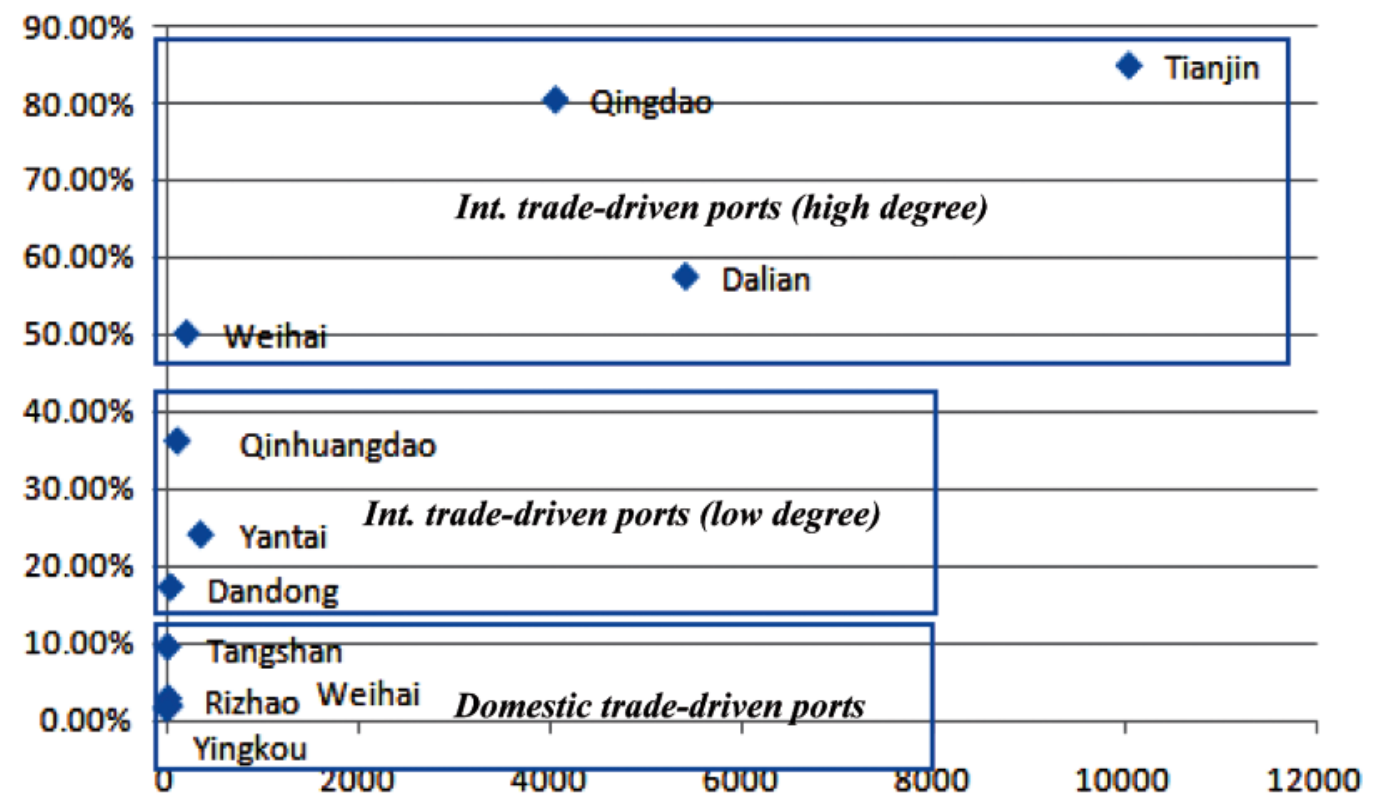

Fig. 4. Port category according to foreign trade cargo traffic 
a regional center that requires more sophisticated functions in logistics system. Third, there is no clue that SMPs in different port clusters have direct competition. The fourth analysis on the port competition is developed among small and medium-sized ports in the BER. In contrast to direct competition between medium-sized and hub ports, this category contains more cooperation, and merger $\&$ acquisition cases are more prevalent among these ports. For example, in 2005, Yingkou port acquired Jinzhou port by taking its advantage of oil transportation, and in 2012 Yingkou was negotiating with Dandong port for further merger. Similar to the third category, competition among these ports is also restricted to the same region.

\subsection{The role of SMPs in the relative port cluster}

The role of SMPs in a multi-port gateway region varies in the whole supply chain. Some ports transship cargoes from hub ports and function as complements or assisting ports, while in contrast, other ports challenge the dominant position of centrality ports as substitutes with their rapid expansion in market competition. In the BER, "substituting" SMPs can be found in Liaoning and Jin-Ji ports region, and relationship between Dalian and Yingkou (Liaoning) as well as Tianjin and Qinhuangdao (Jin-Ji) is described as direct competition between incumbent hub ports and new emerging sub-hub ports. The possibility of dual-hub ports in specific regions receives attention from academic concerns (Wang, 2012). Though dual-hub ports can attract more cargoes and enhance overall competitiveness of such region, new risks may undermine this plausible blooming picture. On the one hand, the rise of sub-hub ports, conceived as medium-sized ports in this paper, will put more competition on hub ports. On the other hand, hub ports need to either expand port size or improve efficiency to maintain port attractiveness. Some hub ports choose to construct new berth in a location near those sub-hub ports or accelerate pace in acquiring more small ports to enhance their competitive positions, i.e. in 2010 Dalian port acquired Lvshun ports which is closer to Yingkou and inland port of Shenyang in order to compete with adjacent Yingkou port. Counter measures of Yingkou port was taken such as expanding scale and acquiring the Dandong Port in 2012. This round of escalating ports consolidation restructured Liaoning ports cluster and dualhub ports pattern in this region is going to emerge. However, expanding port size does not guarantee increasing attractiveness and in the background of volatile economy, both ports are facing problem of over capacity.

However, not all SMPs choose to expand port size when competing with hub ports. for the purpose of competitive advantage, most SMPs remain in their niche market in dealing with specific cargoes to "avoid" direct competition with those centrality ports. This competition system, to a large extent, keeps the multi-port gateway regions comparatively stable. In the BER, all three hub ports mainly deal with international trade cargoes and containership, while the rest of SMPs handle more bulk cargoes and domestic trade cargoes, and most SMPs find specific transportation cargoes in spite of overlapping hinterland (Table 8).

Another way to analyze SMPs' role in relative port cluster and economic region is how they contribute to the overall port networking. We compare the transshipment of SMPs because this indicator can measure the frequency that SMPs can connect with other ports. Five SMPs serve high degree of domestic trade container transshipment different from big ports (Table 9).

Tab. 8. Cargo classification of SMPs in the BER

\begin{tabular}{|c|c|c|}
\hline Port cluster & Ports & Cargo classification \\
\hline \multirow{3}{*}{ Liaoning } & Yingkou & Mineral, Iron and Timber \\
\cline { 2 - 3 } & Jinzhou & Timber, Textile products and Iron \\
\hline \multirow{3}{*}{ Shandong } & Yantai & Agricultural products and Iron \\
\cline { 2 - 3 } & Rizhao & Petroleum and Mineral \\
\cline { 2 - 3 } & Weihai & Mine construction materials, Coal and Rubber \\
\hline \multirow{2}{*}{ Jin-Ji } & Qinhuangdao & Coal \\
\cline { 2 - 3 } & Tangshan & Coal and agricultural products \\
\hline
\end{tabular}

Tab. 9. Transshipment volume of SMPs in the BER (TEU)

\begin{tabular}{|c|c|c|c|c|c|c|c|c|c|}
\hline \multirow{3}{*}{$\begin{array}{c}\text { Port } \\
\text { Region }\end{array}$} & \multirow{3}{*}{ Port } & \multirow{2}{*}{\multicolumn{2}{|c|}{$\begin{array}{c}\text { Total Container } \\
\text { Transshipment } \\
\text { Volume }(\mathrm{A}+\mathrm{B}+\mathrm{C})\end{array}$}} & \multicolumn{4}{|c|}{ Foreign Trade Container transshipment } & \multirow{2}{*}{\multicolumn{2}{|c|}{$\begin{array}{l}\text { Domestic Trade } \\
\text { Container } \\
\text { transshipment (C) }\end{array}$}} \\
\hline & & & & \multicolumn{2}{|c|}{$\begin{array}{c}\text { international } \\
\text { Container } \\
\text { transshipment (A) }\end{array}$} & \multicolumn{2}{|c|}{$\begin{array}{c}\text { Export and Import } \\
\text { Trade transshipment (B) }\end{array}$} & & \\
\hline & & 2010 & 2009 & 2010 & 2009 & 2010 & 2009 & 2010 & 2009 \\
\hline \multirow{3}{*}{ Liaoning } & Dalian & $581169 *$ & $388397 *$ & 99186 & 32813 & 269940 & 286198 & - & - \\
\hline & Yingkou & 389785 & 232197 & - & - & - & - & 389785 & 232197 \\
\hline & Jinzhou & 115 & 1721 & - & - & - & - & 115 & 1721 \\
\hline \multirow{2}{*}{ Jin-Ji } & Tianjin & 193368 & 44049 & 79180 & 9878 & 81027 & 1823 & 33161 & 32348 \\
\hline & Qinhuangdao & 79 & 18397 & 27 & - & - & - & 52 & 18397 \\
\hline \multirow{3}{*}{$\begin{array}{l}\text { Shandong } \\
\text { Bay }\end{array}$} & Qingdao & 730393 & 631132 & 132696 & 49250 & 591118 & 572174 & 6579 & 9708 \\
\hline & Yantai & 715601 & 682897 & - & - & - & - & 715601 & 682897 \\
\hline & Rizhao & 13187 & 1535 & - & - & - & - & 13187 & 1535 \\
\hline
\end{tabular}

Note: all transshipment volumes refer seaborne transshipment in between seaports. Data of river-sea transshipment are not available except for Dalian. In 2010 and 2009, 212043 and 102199 TEU were transported between river and sea respectively. Source: China port year book 2011. International container transshipment (A): containers loading by the ports in the BER through foreign ports then to export. Export and import trade transshipment (B): containers loading by the ports in the BER through other Chinese ports then to export. 
Their role in connecting domestic transshipments within a multi-port gateway region is more prominent compared to international connectivity. SMPs in the regions of Liaoning and Shandong undertake high ratio of transshipment compared to their adjacent hub ports. While in contrast, in the Jin-Ji region, the gateway port of Tianjin undertakes more than $90 \%$ of total transshipment volumes. In other words, SMPs in Liaoning and Shandong are more dynamic in the relative port clusters. Their role in transiting domestic containers compensates the shortcoming of adjacent gateways ports; in a result, less intense competition in transshipment market promotes SMPs for the fast growth. The "complement relations" between SMPs and gateway ports in the transshipment market reinforce.

In general, most SMPs in the BER are competitive in niche segment markets and function as a "complement" to hub ports, and the rise of SMPs also makes a port networking complex in such regions. Some SMPs choose to cooperate with the hub ports, for example, in Shandong Bay, a new port system is planned by positioning Qingdao as a gateway port, Yantai and Rizhao as assisting ports (medium sized ports) and Weihai as feeding ports (small ports). Assisting ports will develop more international shipping lines while feeding ports engage in domestic markets. Some SMPs with the rapid increases can form direct competition over the big ports and relations between these ports are more like "substitutes", such as the port of Dalian and Yingkou. The new emerging SMPs, like Yingkou ports, will implement more mergers and acquisitions for port expansion to gain more competitive advantage in competing with ports much larger than its size.

\section{PORT CITY AND HINTERLAND CHARACTERISTICS OF SMPS}

In this section, we analyze the interactions between SMPs and their hinterland capture. A distinction is made between the direct hinterland of the port and the more distant/extended hinterland. Hinterland access is one of the important factors that influence the competitiveness of a seaport when it competes with other ones.

The direct hinterland refers to the port city region and the extended hinterland is the coverage of a port where cargoes are transported from and to. Port cities were settlements, where cargoes were interfaced between land and ocean and where related businesses emerged about fifty years ago. However, correlation between ports and cities has changed a lot, i.e., a large city does not necessarily have a large port (e.g., London) and vice versa (Talley 2009). Some big cities may have a small port (e.g., the U.S. cities San Diego, Philadephia, Boston, etc.). The rationale is that the case for the cities can emerge "through agglomeration forces generated by the interaction of increasing returns and transport costs" (Fujita and Mori 1996).

In the BER, all three gateways ports (big ports) are accompanied with big cities and GDPs from these port cities rank in a sequent order that accords with corresponding port cargo volumes (Table 10). This correlation has been enhanced through institutional and policy effects, Tianjin expands its city area to the Binhai new city and Dalian port benefits from an economic revitalization policy issued in 2006. However, ports have no too direct relation with cities in a group of the medium-sized ports. For instances, GDP of Yantai city ranked the sixth position with 435.85 billion Yuan in 2011, while the cargo volumes of Yantai port were the eighth in the BER, and is the smallest port among all medium-sized ports. The production output of port city seems to be no impact on port freight expansion. Similarly, large size of Yingkou port doesn't generate quasi big city because the GDP of Yingkou city is the smallest of all eleven study samples. This inconsistence also applies into small ports, such as Jinzhou port.

From the perspective of port cities, the industrial distribution and transportation demand will affect port attractiveness for cargoes. Like Jinzhou, the city close to Beijing with convenient rail and road connection with the adjacent big cities and most generated transportation demand can be satisfied through land transportation. On the other side, the extended hinterland yields more crucial effect on SMPs' freight, and next, we'll take the Yingkou Port for example for an in-depth analysis on how the extended hinterland affects SMPs.

We collect data from the inside of the Yingkou Port that is classified in terms of two dimensions: inbound and outbound cargo volumes through Yingkou port. Connecting ports and cargoes with few volumes are ignored in this paper (Table 11). In composing of outbound cargo volume, the Yingkou port exerts a moderate effect on the BER economy, and cargo volume exported from Yingkou port to the rest BER ports accounts for $12.3 \%$ of total cargo volumes, in comparison, more cargoes are imported to Yingkou port through the BER ports and corresponding figure reaches to $27.5 \%$. The main demand for the Yingkou port is distributed in the south of China, for example, two regions of Guangdong and Shanghai make up the largest proportion of Yingkou port cargo volumes. The extended hinterland supports Yingkou port's freight more than the port city does. In other words, niche market for SMPs

Tab. 10. Port cargo volume and port city GDP rank in 2011

\begin{tabular}{|c|c|c|c|c|c|c|}
\hline $\begin{array}{c}\text { Port cargo } \\
\text { volume rank } \\
\text { in the BER }\end{array}$ & $\begin{array}{c}\text { Port cargo } \\
\text { volume rank } \\
\text { Nation wide }\end{array}$ & $\begin{array}{c}\text { Port } \\
\text { (City/region) }\end{array}$ & $\begin{array}{c}\text { Total cargo } \\
\text { volume in } \\
\text { million tons }\end{array}$ & $\begin{array}{c}\text { Port City GDP } \\
\text { in Billion Yuan } \\
\text { (RMB) }\end{array}$ & $\begin{array}{c}\text { Port city GDP } \\
\text { Rank in the } \\
\text { BER }\end{array}$ & $\begin{array}{c}\text { Port city GDP } \\
\text { rank Nation } \\
\text { wide }\end{array}$ \\
\hline 1 & 3 & Tianjin & 451.00 & 910.88 & 1 & 6 \\
\hline 2 & 5 & Qingdao & 375.00 & 566.62 & 2 & 10 \\
\hline 3 & 6 & Dalian & 338.00 & 515.8 & 3 & 14 \\
\hline 4 & 7 & Qinhuangdao & 287.00 & 93.05 & 9 & 127 \\
\hline 5 & 8 & Tangshan & 308.00 & 446.9 & 4 & 19 \\
\hline 6 & 9 & Yingkou & 261.00 & 100.24 & & 119 \\
\hline 7 & 10 & Rizhao & 250.00 & 102.51 & & 115 \\
\hline 8 & 12 & Yantai & 180.00 & 435.85 & 5 & 10 \\
\hline 9 & - & Jinzhou & 72.00 & 90.26 & & 11 \\
\hline 10 & - & Dandong & 76.37 & 72.89 & & 11 \\
\hline 11 & - & Weihai & 55.01 & 194.47 & & 6 \\
\hline
\end{tabular}


Tab. 11. Inbound and outbound cargo volumes of Yingkou port 2010

\begin{tabular}{|c|c|c|c|c|}
\hline \multirow{2}{*}{ Rank } & \multicolumn{2}{|c|}{ Outbound } & \multicolumn{2}{c|}{ Inbound } \\
\cline { 2 - 5 } & Port & $\begin{array}{c}\text { Total cargo } \\
\text { volume }\end{array}$ & Port & $\begin{array}{c}\text { Total cargo } \\
\text { volume }\end{array}$ \\
\hline $\mathbf{1}$ & Guangdong & 24217.18 & Guangdong & 16453.11 \\
\hline $\mathbf{2}$ & Shanghai & 17237.64 & Shanghai & 12540.21 \\
\hline $\mathbf{3}$ & Jiangsu & 15900.89 & Fujian & 9440.32 \\
\hline $\mathbf{4}$ & Fujian & 10346.64 & Jin-Ji & $\mathbf{7 8 9 1 . 2 8}$ \\
\hline $\mathbf{5}$ & Zhejiang & $\mathbf{5 8 6 2 . 3 2}$ & Shandong Bay & 7799.36 \\
\hline $\mathbf{6}$ & Shandong Bay & $\mathbf{4 1 0 9 . 3 2}$ & Zhejiang & 6010.42 \\
\hline $\mathbf{7}$ & Liaoning & $\mathbf{3 8 2 2 . 1 4}$ & Jiangsu & 5347.51 \\
\hline $\mathbf{8}$ & Jin-Ji & $\mathbf{2 5 7 0 . 5 3}$ & Liaoning & $\mathbf{3 3 7 3 . 8 7}$ \\
\hline $\mathbf{9}$ & Guangxi & 829.38 & Guangxi & 273.52 \\
\hline $\mathbf{1 0}$ & Anhui & 710.76 & Anhui & 90.42 \\
\hline $\mathbf{1 1}$ & Hainan & 28.68 & Hubei & 85.13 \\
\hline $\mathbf{1 2}$ & Hubei & 7.17 & Hainan & 20.02 \\
\hline $\mathbf{1 3}$ & & & Jiangxi & 11.37 \\
\hline Total & & $\mathbf{8 5 6 4 2 . 6 5}$ & & $\mathbf{6 9 3 3 6 . 5 3}$ \\
\hline
\end{tabular}

Thousand tons except noted.

Source: authors' elaboration on Yingkou port annual report 2010.

not only refers to cargo classification as introduced above, but also their attractiveness to transport cargoes to further regions in order to avoid intense competition over overlapping hinterland. However, individual case can't represent all cases of SMPs and further research into more cases can justify how extensive hinterland can enhance the role of SMPs in multiport gateway regions.

\section{LOGISTICS AND DISTRIBUTION FUNCTION OF SMPS}

A seaport is a logistic and industrial node in the global transport system with a strong maritime character and in which a functional and spatial clustering of activities takes place. Activities that are directly or indirectly linked to seamless transportation and transformation process within the logistic chains (OECD, 2000). But seaports are complex and dynamic entities, often dissimilar from each other, where various activities are carried out by and for the account of different actors and organizations. Such a multifaceted situation has led to a variety of operational, organizational and strategic management approaches to port systems (Bichou and Gray, 2005). The current logistics nodes overlap in terms of function resulting in weak scale economies, so as to the role of SMPs and gateway ports in the same logistics system. A variety of methods in evaluating ports logistics and distribution functions have been applied, such as DEA (data envelopment analysis) method. Qi and Han (2006) assessed port logistics function efficiency by using DEA and drew a conclusion that Dalian port is more efficient than Yingkou, Dandong and Jinzhou. However, such conclusion is based on infrastructure as an input and cargo volumes as an output, such as yard area and berth length, while ignoring the inland port connection and multimodal transportation. The whole logistics industry in the BER is characterized by small scale businesses which offer basic logistics services such as warehousing and transportation. The inland port facilities and optimized logistics nodes should conform to three criteria: direct link to a seaport; high capacity transport link(s) and availability of services found in a seaport
(Roso and Lévęque, 2002). To enhance ports' role in logistics system, gateways ports of Tianjin, Qingdao and Dalian chose to establish logistics parks and container logistics center that are located close to ports by providing warehousing and other value added services. For instances, three logistics centers were set up in the Dalian port, and Shenyang and Harbin serving for containers pick-up and loading business. Compared to selfestablished logistics infrastructures, SMPs seek to cooperate with inland cities by co-setting up inland ports to attract more cargoes from inland areas. Yingkou port utilizes inland port in Shenyang to expand its intermodal transportation and function in the whole logistics system. Whereas, inland connection among SMPs is less stressed in the Jin-Ji region and the Shandong Bay, and the main reason is that in these two regions, SMPs haven't formed direct competition over gateways ports. As a result, the logistics function of SMPs has been ignored. The dominant difference between logistics park and inland port in the BER lies in governance. Logistics parks are usually solely invested by port authority, where inland ports usually are launched by inland city governments and port authorities by agreement to invest or take share in part of infrastructures. Therefore, in the BER region the logistics system lacks the scale and the sophistication in order to cope with the increasing demand for modern logistics concepts. The role of SMPs in the whole logistics system or vice versa hasn't been improved in accord with their throughput growth.

Besides, intermodal transportation is another indicator in assessing the SMPs' logistics function. Intermodal connectivity and landside access to Chinese ports are not approached differently or in a more sophisticated way than in the United States or European Union. Many new built port facilities are located in large urban areas, and the access to and from these ports involves traversing mixed-use roadways (ITSP, 2008). In China, rail access to seaborne port hasn't gained enough investment, and railroad-sea (mainly containers) shipment accounts for more than $95 \%$ of total intermodal transportation. However, due to the increasing pressure from volatile oil price and demand for less emission, the intermodal transportation for rail-sea containers (RSC) receives more attention from 
policymakers and practitioners. From international port experience, such transportation methods with high efficiency occupy high weight in a mature port, for example, about $13 \%$ of cargoes are transported from RSC in the port of Rotterdam and $11 \%$ in the New Jersey port respectively. While in contrast, the ratio is relatively low to average $2 \%$ in China, $84 \%$ of cargoes are transported through road-sea, and $14 \%$ are in between waterway and even lower in SMPs. In the BER, medium-sized ports bear less RSC transportation shares except for Yingkou port, and it came to 170,000 TEU containers through RSC, accounting for $7.6 \%$ of total container freight in 2009 . The rest of SMPs only take up less than $0.5 \%$ of RSC cargoes. In contrast, in the adjacent gateways ports, the Dalian port has transported 250,000 TEU containers through RSC, accounting for more than $5 \%$ of total container freight. Tianjin and Qingdao are next to these ports, making up $2 \%$ and $0.8 \%$ respectively. SMPs in the BER are in a low ratio in terms of RSC transportation. One reason is that most SMPs in the BER handle much less containers compared to their bulk cargo volumes. The other reason is that most cargoes now are manufactured in coastal areas that are close to ports, with less need for long distance of railway transportation. However, with increasing labor and land costs, parts of manufacturing factories are transferred to more inland areas. RSC transportation could be another niche market for SMPs. Some SMPs in the BER are already committed to exploring this market to develop containerships. For example, in Yingkou, three newly-developed sea-rail express routes with two days a shift are operated by COSCO, while the neighboring gateway ports of Dalian manage two routes and one of them is in a daily shift. Besides, Rizhao port also tries to develop such intermodal transportation to seek a more competitive position in logistics system of the BER.

Overall, we can conclude some typical characteristics in describing the profile of SMPs in the BER, and ports with annual cargo volume of less than 150 million tons are defined as SMPs (Table 12). Most SMPs in the BER are driven by domestic trade cargoes and competitive in bulk cargo market. Consequently, the less dependence on the world spoke \& hub system retains SMPs to niche markets. Compared to the gateway ports, the market shares of those SMPs are increasing rapidly, and in specific regions, this fast market expansion even challenges the dominant position of neighboring gateway ports. To enhance or maintain the competitive position, some SMPs may choose agglomerations that contribute to port networking in such regions and we found more cooperation in between SMPs. When studying correlations between SMPs and port city/ hinterland, we found less connection between ports city GDP growth and throughput, and the freight of SMPs may depend more on extensive hinterland and connection with inland ports.
However, the medium-sized ports differ from small ports. The peripheral challenge by SMPs refers to medium-sized ports only as there is no evidence that small ports can form direct competition on medium-sized port or gateways ports.

\section{CONCLUSION}

Difference between SMPs and gateway ports concerns not only the size of a port but endogenous heterogeneity. Every big port has experienced the start-up stage and evolves into the centrality position but not all the SMPs can grow into large ports. The main reason is how SMPs survive and maintain their competitive advantage in the highly competitive multi-port gateway regions. Some SMPs retain their capacity in specific niche markets or undertake transshipment to avoid competition from the hub ports. While other SMPs that intend to challenge the dominant position of gateway ports demonstrate the similarities. Firstly, port classification regarding part of SMPs and gateway ports is of clear divisional function. And they are either international trade or domestic commerce driven. In other words, relation between SMPs and gateway ports is more like "complements". Moreover, this relationship contributes to the relatively stable status in a multi-port gateway region and leaves enough space for development of SMPs. Secondly, with the rise of individual SMPs, this "complements" relation evolves into "substitutes", and gateway ports capture cargoes previously predominated by SMPs. This competition, to some extent, may result in vicious circle and overcapacity as both competitors are expanding port sizes rapidly when they seek the economies of scale. The other risk is that this escalating competition will undermine the complete logistics system and reduce the whole region's competitiveness in terms of logistics efficiency in confronting with the external challenges. The rest SMPs will choose to either maintain in their niche markets or cooperate with leading ports that will trigger the port consolidation and bring synergy effect. Therefore, the competition system in such multi-port gateway regions will evolve into a more dynamic and growing port cluster, in which, SMPs act like nodes connecting relevant stakeholders.

The three-level port classification by employing multidimension variable methods provides an in-depth analysis into the ports categories, and can be employed to describe the profile of SMPs, mainly from the role of SMPs in a competitive context. The further research will focus more on internal operation management of SMPs, for example, how to evaluate SMPs' performance, institutional factor on their developments, SMPs' role on enhancing multi-port gateway region's competiveness, etc. The purpose is to find a compound research method to assess SMPs. Another issue concerned is

Tab. 12. Characteristics of SMPS and hub ports in the BER

\begin{tabular}{|c|c|c|}
\hline Characteristics & SMPs & gateway ports \\
\hline Port size & $\begin{array}{c}\text { Medium size: cargo volume of 150-300 million tons } \\
\text { Small size: cargo volume of less than 150 million tons }\end{array}$ & Cargo volume of over 300 million tons \\
\hline Port classification & Domestic trade driven & International trade driven \\
\hline Cargo & Bulk & Container \\
\hline Market share & Increasing & Stable to decreasing \\
\hline World spoke \& hub system & Less connected & Connected \\
\hline Port-city & Less correlated & Logistics park \\
\hline logistics system & Inland port connection & Competition \\
\hline Port networking & Co-petition & connected \\
\hline Intermodality & Less connected & \\
\hline
\end{tabular}


the generalized application study on more SMPs worldwide that needs exploring more cases studies, especially in more extremely different regions.

The above characteristics for SMPs in the BER may change because of two factors: decrease of international trade due to volatile global economy and future free trade zone between Korea, Japan and China. The decline of international trade may force hub ports to switch to domestic trade and competition between hub ports and SMPs will change as well. The other factor is the proceeding of the free trade zone (FTZ) between neighboring three countries of China, South Korea and Japan. If FTZ is established, on the one hand, all ports will receive more cargoes and benefit from more convenient cargoes transferring. In other words, the overall throughput and port attractiveness in the north of Asia will improve, but both SMPs and hub ports in the north of China will face competition from Korea and Japan so that the previous port relations will be broken and the competition will surpass the current boundary restriction.

\section{REFERENCES}

1. Bichou, K. and Gray, R. (2005) 'A critical review of conventional terminology for classifying seaports', Transportation Research A, Vol. 39 No. 1, pp.75-92

2. De Langen, P. (2004) 'Governance in Seaport Clusters', Maritime Economics \& Logistics, Vol. 6, pp.141-156

3. Ding, D., Koay, P. Y., and Teo, C.-P. (2009) 'Port's growth: Does size matter?', Proceedings of the Asia Pacific Maritime Conference Presentation, Singapore, pp.1-33

4. Feng, L., and Notteboom, T. (2011), Small and Medium-Sized Ports (SMPs) in Multi-Port Gateway Regions:the Role of Yingkou in the Logistics System of the Bohai Sea, Current Issues in Shipping, Ports and Logistics, ASP: Brussels, pp.543563

5. Freight mobility and intermodal connectivity in China, International technology scanning program, ITSP, U.S. Department of Transportation, 2008

6. Fujita, M. and Mori, T. (1996) "the role of ports in the making of major cities: self-agglomeration and hub-effect", Journal of development economics, 49:93-120

7. Guo, S.H., Lin, Z.J., Hong, X.Q., She, R.X. (2009) 'On the application of composite index method based on entropy authority to the water quality evaluation',Environmental Science and Management, Vol. 34 No. 12, pp.165-167

8. Li, Y.H., Hu, Y.Q. (2006) 'A model of multilevel fuzzy comprehensive evaluation for investment risk of high and new technology project', Proceedings of 2006 International Conference on Machine Learning and Cybernetics, China, pp.1942-1947

9. Liang, Z.H., Yang, K., Sun, Y.W., Yuan, J. H., Zhang, H.W. and Zhang, Z. H. (2006)'Decision support for choice optimal power generation projects: Fuzzy comprehensive evaluation model based on the electricity market', Energy Policy, Vol. 34, pp.3359-3364

10.Lirn, T. C., Thanopoulou, H. A., Beynon, M. J., Beresford, A. K. C. (2004) 'An application of AHP on transhipment port selection: a global perspective', MaritimeEconomics \& Logistics, Vol. 6, pp.70-91

11.Nijdam, M. (2010) 'Leader firms: the value of companies for the competitiveness of the Rotterdam seaport cluster',ERIM PhD Series in Research in Management, No. 216, EUR:Rotterdam

12.Notteboom, T. (2005) 'The peripheral port challenge in container port systems', in Leggate, H., Mcconville, J., Morvillo, A. (Eds.), International Maritime Transport: Perspectives, Routledge, London, pp.173-188
13.Notteboom, T. (2010) 'Concentration and the formation of multi-port gateway regions in the European container port system: an update', Journal of Transport Geography, Vol. 18 No. 4, pp.567-583

14.Notteboom, T. (2011) 'An application of multi-criteria analysis (MCA) to the location of a container hub port in South Africa', Maritime Policy and Management, Vol. 38, No. 1, pp. 51-79

15.Notteboom, T., Rodrigue, J.-P. (2005) 'Port regionalization: towards a new phase in port development', Maritime Policy and Management, Vol. 32 No. 3, pp.297-313

16.Notteboom, T., Rodrigue, J.-P. (2009) 'Inland terminals within North American and European supply chains', Transport and Communications Bulletin for Asia and the Pacific, UN ESCAP, No. 78, pp. 1-39

17.Notteboom, T., Winkelmans, W. (2001) 'Structural changes in logistics: how will port authorities face the challenge?', Maritime Policy and Management, Vol. 28 No. 1, pp. 71-89

18.Pallis, A., Vitsounis, T., De Langen, P., Notteboom, T. (2011) 'Port Economics, Policy and Management: Content Classification and Survey', Transport Reviews, Vol. 31 No. 4, pp.445-471

19.Qi, X., and Han, Z. L., (2005), "Major ports logistics efficiency analysis in Liaoning, China", Ocean Development and Management, pp.22-26

20. Robinson, R. (2002) 'Ports as elements in value-driven chain systems: the new paradigm', Maritime Policy and Management, Vol. 29 No. 3, pp. 241-255

21.Roso, V., and Lévęque, P. (2002), 'dry port concept for seaport inland access with intermodal solutions,' master thesis, Chalmers University of Technology, Gothenburg

22.Slack, B., Wang, J.J. (2002) 'The challenge of peripheral ports: an Asian perspective', Geojournal, Vol. 65 No. 2, pp.159-166

23.Talley, W.K, (2009), 'Port Economics', Routledge, Oxon, UK, pp. 136-143

24.Wang, C.J., WANG J., and Ducret, C. (2012), Peripheral Challenge in Container Port System: A Case Study of Pearl River Delta, Chin. Geogra. Sci., pp. 97-108

25.Wilmsmeier, G., Bergqvist, R., Cullinane, K. (2011), 'Special Issue: Ports and hinterland - Evaluating and managing location splitting', Research in Transportation Economics, Vol. 33 No. 1, pp. $1-5$

26.Zhang, A. (2009) 'The Impact of Hinterland Access: Conditions on Rivalry between Ports', inOECD/ITF (Ed.), Port Competition and Hinterland Connections, Round Table no. 143, OECD International Transport Forum (ITF), Paris, pp.129-160

27.Zhao, Y.F., Chen, J.F. (2004) 'Analytic hierarchy process and its application in power system', Electric Power Automation Equipment, Vol. 24 No. 9, pp.85-88

\section{CONTACT WITH THE AUTHORS}

Lin Feng*, Ph.D., Lecturer

Dalian Maritime University (China)

1\#, Linghai Road, Hi-tech zone, Dalian, China, 116023 and

ITMMA - University of Antwerp (Belgium) e-mail: fnlin@126.com

Theo Notteboom, Ph.D., Professor and President, ITMMA - University of Antwerp (Belgium) Kipdorp 59, BE-2000 Antwerp, Belgium and

Antwerp Maritime Academy (Belgium) e-mail: theo.notteboom@ua.ac.be

\footnotetext{
* Corresponding author
} 